\title{
THE EFFECT ANALYSIS OF MARKETING MIX ON PURCHASE DECISIONS AND CUSTOMER LOYALTY USING STRUCTURAL EQUATION MODELING METHOD
}

\author{
(Case Study: Lollypop Shop Surabaya) \\ Suparto \\ Industrial Department, Industrial Technology of Faculty, Institut Teknologi Adhi Tama Surabaya \\ email: $\underline{\text { suparto@itats.ac.id }}$
}

\begin{abstract}
Absract
Distros have been known by the general public especially millennial who are fond of the brand or brand image of a product. The number of very tight competition makes Lollypop Shop Surabaya as one of the distributions that are in need of designing the right marketing strategy. The purpose of this study was to determine the effect of $4 P$ marketing mix variables consisting of products, price, place and promotion of purchasing decisions and customer loyalty as a consideration of business owners in determining marketing strategies. Data analysis was performed using the Structural Equation Modeling (SEM) method which involved 120 respondents obtained from the purposive sampling method. The results of the analysis show that product and promotion variables have a positive and significant effect on purchasing decisions. Price and place variables have a positive but not significant effect on product purchasing decisions. Product variable is the variable that most influences the purchasing decision of Lollypop Shop Surabaya products with product variants as the indicators most desired by consumers.
\end{abstract}

Keywords: marketing mix, purchasing decisions, customer loyalty, structural equation modeling

\section{INTRODUCTION}

Clothing is one of the three basic human needs, namely clothing, food, and shelter. The term clothing comes from the Sanskrit language which has the connotation of "good or beautiful" that is beautiful clothing, comfortable to wear, pleasing to the eye, and suitable for the wearer. It is undeniable that every day all humans must need clothes for daily activities (Komunda and Osarenkhoe, 2012). Starting from the age of toddlers to seniors both in terms of men or women must assume the same clothing needs with food needs that can not be left anytime and anywhere. But in the statement certainly not all have the same priority measures in terms of clothing. Some think clothes aren't too important and some others might think clothes are very important.

In this study not all of the people described were used as research objects. Here the researchers intend to take one or a certain age range as an object of research (Gummesson, 2011). The choice of age range is intended to make this study more targeted. The intended age range is that researchers have chosen millennial or better known as young people as the object of research. Because in this day and age who are more concerned with the need for clothing for daily activities are the millennial (Prabowo and Setiawan,. Because millennials prioritize the interests of fashion over other functions of clothing. Moreover, a stronger reason is that young people will feel proud if the clothes used are not well-known or unbranded (Bendapudi \& Leonard, 2007). From this statement it is certainly a great opportunity for entrepreneurs in clothing outlets for young people, better known as distributions. Every month in one year the sales that occur are unstable or always experience ups and downs that are even more likely to fall (Zineldin, 2006). This is what drives researchers to analyze the place with the aim to increase sales through marketing. 


\section{LITERATURE REVIEW}

\section{Marketing, Purchasing Decision and Customer Loyalty \\ The marketing mix according to} Sivakumar and Raj (2016) is the marketing mix, the set of tactical marketing tools that the firm blends to produce the response it wants in the target market, which means a set of marketing tools integrated to process the responses desired by the target market (Bloemer, et al, 2009).

Purchase Decisions explained that the purchasing decision indicators are as follows (Anderson and Narus, 2014): (a) Interest in buying because of a need or desire; (b) Buying decisions on the basis of information and related sources; (c) The decision to buy after making an assessment and selection of various alternatives; (d) Purchase decisions from recommendations of others.

According to Roig, et al (2006) customer loyalty is defined as the loyalty shown by customers. Some indicators used to measure customer loyalty variables are (Ovidiu \& Brad, 2010): (a) make regular repurchases (makes regular repeat purchases); (b) make purchases outside the product / service line; (c) recommend products (referred to other); (d) demonstrate immunity from the attractiveness of similar products from competitors (Lindgreen, et al, 2004).

\section{Structural Equation Modeling (SEM)}

According to Johanudin, et al (2016) structural equation modeling is a common and very useful multivariate analysis technique which includes special versions in a number of other analytical methods as special cases. The next definition says that structural equation modeling is a statistical technique used to build and test statistical models that are usually in the form of causal models (Dwyer, et al, 2017).

Table 1. Goodness of Fit Index Parameter

\begin{tabular}{clc}
\hline No. & Goodness of Fit Index & Cut Off Value \\
\hline 1. & Chi-Square & Expected to be small \\
2. & Significance Probability & $\geq 0,05$ \\
3. & RMSEA & $\leq 0,08$ \\
4. & GFI & $\geq 0,90$ \\
5. & AGFI & $\geq 0,90$ \\
6. & CMIN or DF & $\leq 2,00$ \\
7. & TLI & $\geq 0,95$ \\
8. & CFI & $\geq 0,95$ \\
\hline
\end{tabular}

\section{METHODOLOGY}
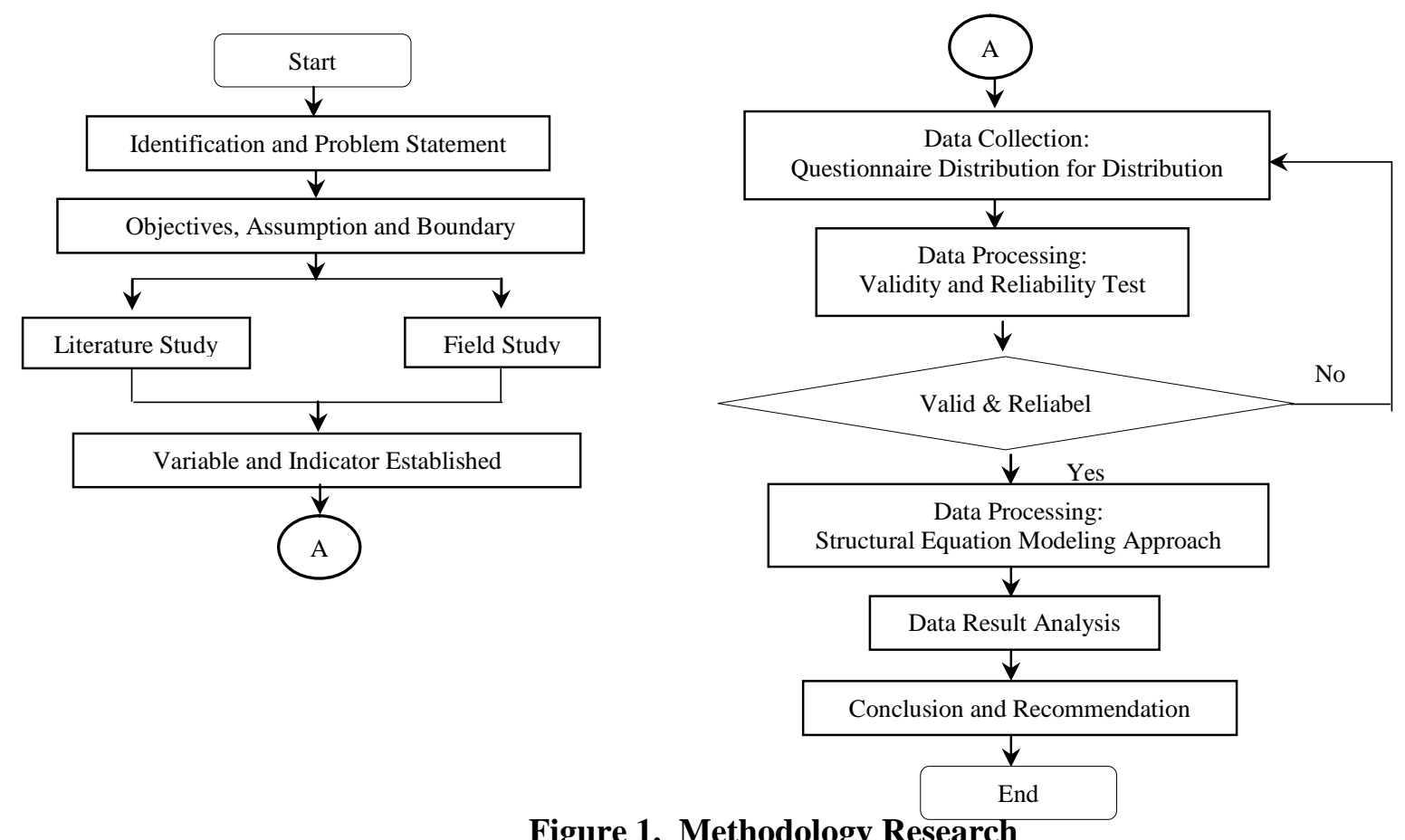

Figure 1. Methodology Research 


\section{RESULT AND DISCUSSION}

From the results of distributing questionnaires to respondents, 120 questionnaires were completed completely and correctly.

Table 2. Profile of Respondent

\begin{tabular}{llcr}
\hline \multicolumn{2}{c}{ Profile of Respondent } & $\begin{array}{c}\text { Number of } \\
\text { Respondent }\end{array}$ & $\begin{array}{c}\text { Percentage } \\
(\%)\end{array}$ \\
\hline Gender & Male & 78 & $65 \%$ \\
Total & Female & 42 & $35 \%$ \\
Usia & $\leq 20$ old & 120 & $100 \%$ \\
Total & $>20$ old & 53 & $44 \%$ \\
Status & Student & 120 & $56 \%$ \\
Total & Employee & 39 & $100 \%$ \\
\hline
\end{tabular}

Validity test measurements on the results of the questionnaire that has been distributed are carried out to ascertain whether the questionnaire is valid or not. In addition, a validity test was used to ascertain whether the questionnaire distributed was sufficiently understood by the respondents or not.

The reliability test of each variable is measured using Cronbach's alpha. Decision making criteria to determine whether the data is reliable or not. If $\mathrm{r}$ count (Cronbach's alpha value) is greater than or equal to 0.600 , then the data is declared reliable. Meanwhile, if the $r$ count (Cronbach's alpha value) is smaller than 0.600 then the item is declared unreliable.

Overall SEM Model Processing

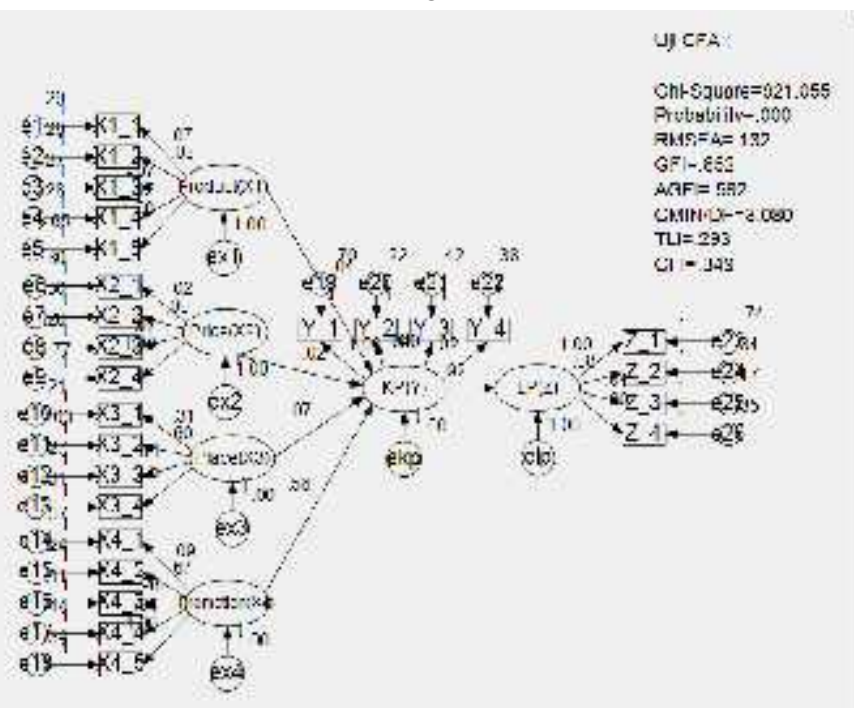

Figure 3. Overall SEM Running Model
The following are the results of the validity and reliability tests of distributing questionnaires to respondents using SPSS Version 17.0, which are presented in the table below:

Table 3. Results of Validity Test

\begin{tabular}{ccc}
\hline Indicator & r Table & Conclusion \\
\hline $\begin{array}{c}\text { Variable of Product } \\
\left(X_{1}\right)\end{array}$ & $>0,179$ & Valid \\
$\begin{array}{c}\text { Variable of Price } \\
\left(\mathrm{X}_{2}\right)\end{array}$ & $>0,179$ & Valid \\
$\begin{array}{c}\text { Variable of Place } \\
\left(\mathrm{X}_{\Xi}\right)\end{array}$ & $>0,179$ & Valid \\
Variable of & $>0,179$ & Valid \\
$\begin{array}{c}\text { Promotion }\left(\mathrm{X}_{4}\right) \\
\text { Variable of }\end{array}$ & & \\
$\begin{array}{c}\text { Purchasing Decision } \\
(\mathrm{Y})\end{array}$ & $>0,179$ & Valid \\
$\begin{array}{c}\text { Variable of } \\
\text { Customer Loyalty } \\
(\mathrm{Z})\end{array}$ & $>0,179$ & \\
\hline
\end{tabular}

Table 4. Result of Reliability Test

\begin{tabular}{cccc}
\hline Indicators & $\begin{array}{c}\text { Cronbach's } \\
\text { Alpha }\end{array}$ & r Table & Conclusion \\
\hline Variable of Product & 0,663 & $>0,600$ & Reliable \\
$\left(X_{1}\right)$ & 0,857 & $>0,600$ & Reliable \\
Variable of Price $\left(\mathrm{X}_{2}\right)$ & 0,742 & $>0,600$ & Reliable \\
Variable of Place $\left(\mathrm{X}_{4}\right)$ & 0,779 & $>0,600$ & Reliable \\
$\begin{array}{c}\text { Variable of Promotion } \\
\left(\mathrm{X}_{4}\right)\end{array}$ & 0,754 & $>0,600$ & Reliable \\
$\begin{array}{c}\text { Variable of Purchasing } \\
\text { Decision }(\mathrm{Y})\end{array}$ \\
$\begin{array}{c}\text { Variable of Customer } \\
\text { Loyalty }(\mathrm{Z})\end{array}$ & 0,660 & $>0,600$ & Reliable \\
\hline
\end{tabular}

Then the evaluation stage is carried out to test the suitability of the model. The model is said to be good if the conformity value of the model (goodness of fit) meets all the criteria. Goodness of fit values for the entire SEM model will be presented in the table below:

Table 5. Overall Goodness of Fit SEM Model

\begin{tabular}{llll}
\hline $\begin{array}{c}\text { Goodness of } \\
\text { Fit Index }\end{array}$ & Cut Off Value & $\begin{array}{c}\text { Model's } \\
\text { Result }\end{array}$ & Conclusion \\
\hline $\begin{array}{l}\text { Chi-Square } \\
(\chi 2)\end{array}$ & $\begin{array}{l}\text { Expected to } \\
\text { be Small }\end{array}$ & 921,055 & Not Feasible \\
Probability & $\geq 0,05$ & 0,000 & Not Feasible \\
RMSEA & $\leq 0,08$ & 0,132 & Not Feasible \\
GFI & $\geq 0,90$ & 0,652 & Not Feasible \\
AGFI & $\geq 0,90$ & 0,592 & Not Feasible \\
CMIN/DF & $\leq 2,00$ & 3,080 & Not Feasible \\
TLI & $\geq 0,95$ & 0,293 & Not Feasible \\
CFI & $\geq 0,95$ & 0,349 & Not Feasible \\
\hline
\end{tabular}




\section{TiBuana}

Journal of applied Industrial Engineering-University of PGRI Adi Buana

p-ISSN 2622-2027

$e$-ISSN 2622-2035

Based on the table it can be concluded that the value of Goodness of fit index produced by the structural model has not met the criteria. So that modifications are needed to the model that aims to get a better model. Modification of the

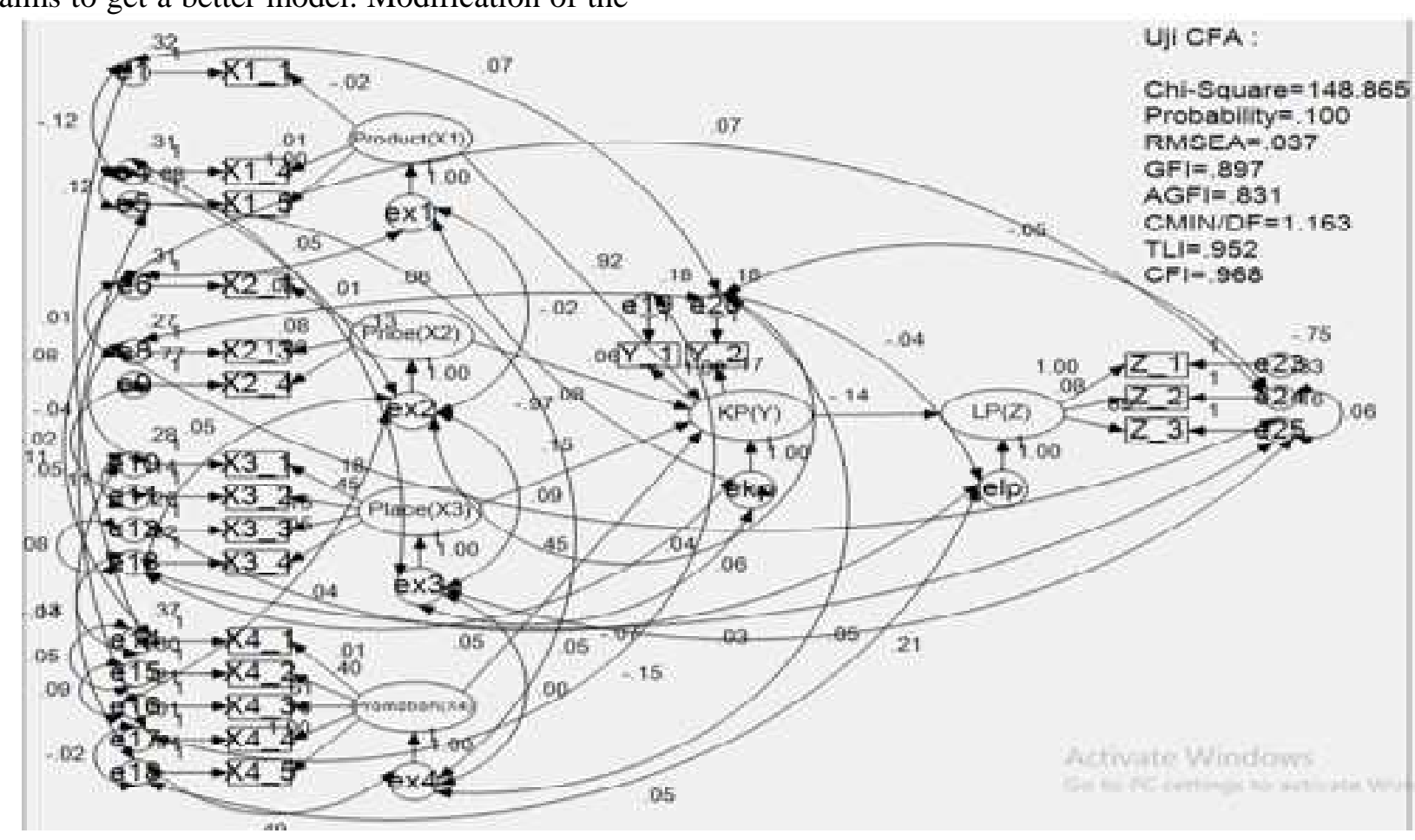

Figure 4. Overall SEM Running Model after Modification

From the overall SEM model image we get the following goodness of fi index results:

Table 6. Overall SEM Goodness of Fit Models after Modification

\begin{tabular}{lcrl}
\hline $\begin{array}{l}\text { Goodness of Fit } \\
\text { Index }\end{array}$ & $\begin{array}{c}\text { Cut Off } \\
\text { Value }\end{array}$ & $\begin{array}{c}\text { Model } \\
\text { Result }\end{array}$ & Conclusion \\
\hline Chi-Square $(\chi 2)$ & $\begin{array}{c}\text { Expected } \\
\text { to be Small }\end{array}$ & 148,865 & Fit Model \\
Probability & $\geq 0,05$ & 0,100 & Fit Model \\
RMSEA & $\leq 0,08$ & 0,037 & Fit Model \\
GFI & $\geq 0,90$ & 0,897 & Fit Model \\
AGFI & $\geq 0,90$ & 0,831 & Fit Model \\
CMIN/DF & $\leq 2,00$ & 1,163 & Fit Model \\
TLI & $\geq 0,95$ & 0,952 & Fit Model \\
CFI & $\geq 0,95$ & 0,968 & Fit Model \\
\hline
\end{tabular}

Table 7. Estimation of Overall

SEM Model Parameters

\begin{tabular}{lcccc}
\hline & Estimation & S.E. & C.R. & P - Value \\
\hline KP $(Y)<---$ Product $\left(X_{1}\right)$ & 0,924 & 0,067 & 13,766 & $* * *$ \\
KP $(Y)<----$ Price $\left(X_{2}\right)$ & 0,057 & 0,036 & 1,556 & 0,120 \\
KP $(Y)<---$ Place $\left(X_{3}\right)$ & 0,152 & 0,097 & 1,564 & 0,118 \\
KP $(Y)<--$ Promotion $\left(X_{4}\right)$ & 0,449 & 0,065 & 6,927 & $* * *$ \\
LP $(Z)<---$ KP $(Y)$ & $-0,138$ & 0,080 & 1,714 & 0,187 \\
\hline
\end{tabular}

Note: $\mathrm{KP}=$ Purchase Decision, $\mathrm{LP}=$ Customer Loyalty model is carried out by correlating between residual indicators and discarding variables that have no effect or variables that have the smallest effect shown in the figure below: 
factors as shown in the table which shows that the overall SEM model meets the Goodness of fit index criteria. This means that the indicators used in measuring each latent variable are appropriate. The following conclusions from testing 5 hypotheses proposed in this study:

Table 8. Hypothesis Testing

\begin{tabular}{ccl}
$\begin{array}{c}\text { Testing } \\
\text { to }\end{array}$ & Hypothesis & \multicolumn{1}{c}{ Relation } \\
\hline 1 & $\begin{array}{c}H_{0} \\
\text { Rejected }\end{array}$ & $\begin{array}{l}\text { Product factors significantly } \\
\text { influence the purchase } \\
\text { decision factor } \\
\text { The price factor does not } \\
\text { significantly influence the } \\
\text { purchase decision factor }\end{array}$ \\
2 & $\begin{array}{c}H_{0} \\
\text { Accepted }\end{array}$ & $\begin{array}{l}\text { The place factor does not } \\
\text { significantly influence the } \\
\text { purchase decision factor } \\
\text { Promotion factor } \\
\text { significantly influences the } \\
\text { purchase decision factor } \\
\text { The purchase decision factor } \\
\text { does not significantly } \\
\text { influence customer loyalty }\end{array}$ \\
4 & $\begin{array}{c}H_{0} \\
\text { Rejected }\end{array}$ & $\begin{array}{l}H_{0} \\
\text { Accepted }\end{array}$
\end{tabular}

\section{CONCLUSION}

Based on the results of data processing that has been done and also based on the results of data analysis that has been done. So the conclusions obtained in this study include the following:

1. Product Factor has a significant influence on the Purchasing Decision factor at Lollypop Shop Surabaya of 13,766 with a significance level of $\alpha=$ $5 \%$.

2. The Price factor does not have an influence on the Purchase Decision factor at Lollypop Shop Surabaya of 1.556 with a significance level of $\alpha=$ $5 \%$.

3. The Place factor has no influence on the Purchase Decision factor at Lollypop Shop Surabaya of 1.564 with a significance level of $\alpha=5 \%$.

4. Promotion factor has a significant influence on the Purchasing Decision factor at Lollypop Shop Surabaya of 6.927 with a significance level of $\alpha=$ $5 \%$.

5. The Purchase Decision Factor has no influence on the Customer Loyalty factor at the Surabaya Lollypop Shop of $-1,714$ with a significance level of $\alpha=5 \%$.

The suggestions that can be given in this study include the following:

1. Adding a variant of the product so that it can attract new customers and retain old customers so that it helps increase purchasing decision factors and customer loyalty at Lollypop Shop Surabaya.

2. Promoting more often both online and offline media so that new consumers and old customers know more about Lollypop products in order to increase purchasing decision factors and customer loyalty at Lollypop Shop Surabaya.

3. Maintaining products that have been in great demand by consumers and establishing the best possible relationships with new and old customers when conducting promotions in order to create customer loyalty or loyalty at the Lollypop Shop Surabaya.

\section{Reference}

1. Anderson, J.C. and Narus, J.A. (2014). A model of the distributor's perspective of distributor manufacturer working relationship. Journal of Marketing, vol. 48 No. 1, pp. 62-74.

2. Bendapudi, N., \& Leonard, L. B. (207). Customers' Motivations for Maintaining Relationships with Service Providers. Journal of Retailing, 73 (1), 15-37.

3. Bloemer, J., de Ruyter, K. and Wetzels, M. (2009). Linking perceived service quality and service loyalty: A multidimensional perspectives. Journal of Marketing, Vol.33 No.4, pp.1082-106

4. Dwyer, F.R., Schurr, P.H. and Oha, S. (2017). Developing buyer seller relationships. Journal of Marketing, vol. 51 No. 1, pp. 11-27.

5. Gummesson, E. (2011). Marketing revisited: the crucial role of the part time marketers. European Journal of Marketing, vol. 25 No. 2, pp. 60-7.

6. Johanudin Lahap, Nur safiah \& Shelle Mohad Radzi. (2016). A study of brand image towards customer satisfaction in 
Malaysian Hotels Industry. Social and Behavioural science, Science Direct. IRSSM-6 (2015)

7. Komunda .M and Osarenkhoe A. (2012). Remedy or Cure for service failure? Effect of service recovey on customer satisfaction and loyaty. Business Process Management Journal, vol.18 No. 1, 82103

8. Lindgreen, A., Palmer, R. and Vanhamme, J. (2004). Contemporary marketing practice: theoretical propositions and practical implications. Marketing Intelligence \& Planning, vol. 22 No. 6, pp. 673-92.

9. Ovidiu I. Moisescu \& Brad Allen (2010). The relationship between the dimensions o brand loyalty. An Empirical investigation among Romania Urban Consumers. Management and Marketing Challenges for Knowledge Society, vol 5, No.4, pp 83-98.

10. Prabowo, R., \& Setiawan, E. (2019). Integrasi Design for Six Sigma (DFSS) dan TRIZ Pada Bisnis Jasa Rental Sound System Untuk
Peningkatan Keputusan Pelanggan (Studi Kasus: UD. Cakra Music). JISO: Journal of Industrial and Systems Optimization, 2(1), 110.

11. Prabowo, R., Singgih, M. L., Karningsih, P. D., \& Widodo, E. (2020). New Product Development from Inactive Problem Perspective in Indonesian SMEs to Open Innovation. Journal of Open Innovation: Technology, Market, and Complexity, 6(1), 20.

12. Roig, J. C. F., Garcia, J. S., Tena, M. A. M. \& Monzonis, J. L. (2006). Customer perceived value in banking services. International Journal of Bank Marketing, 24, 266-283.

13. Sivakumar, K. and S. P. Raj. (2016). Quality Tier Competition: How Price Change Influences Brand Choice and Category Choice. Journal of Marketing, 61(3), 71-85.

14. Zineldin, M. (2006). The royalty of loyalty: CRM, quality, and retention. Journal of Consumer Marketing, 23(7), 430-43. 